\title{
Is There a Need for Such a Naming: Seronegative Primary Sjogren's Syndrome?
}

\section{Seronegatif Primer Sjögren Sendromu: Böyle Bir İsimlendirme Gerekli mi?}

\author{
(D) Samet Karahan', (D) Aycan Karabulut ${ }^{2}$
}

${ }^{1}$ Kayseri City Training and Research Hospital, Clinic of Internal Medicine, Division of Rheumatology, Kayseri, Turkey

${ }^{2}$ Kayseri City Training and Research Hospital, Clinic of Internal Medicine, Kayseri, Turkey

Cite as: Karahan S, Karabulut A. Is There a Need for Such a Naming: Seronegative Primary Sjogren's Syndrome? Turk J Immunol 2021;9(3):128-33

Received: 14.09 .2021

Accepted: 23.11 .2021

Corresponding Author: Samet Karahan, Kayseri City Training and Research Hospital, Clinic of Internal Medicine, Division of Rheumatology, Kayseri, Turkey Phone: +90 4882134444 E-mail: doktorsamet@yahoo.com ORCID: orcid.org/0000-0003-2065-4047

\begin{abstract}
Objective: Autoantibodies such as rheumatoid factor, anti-nuclear antibody, anti-Ro/SSA, and anti-La/SSB have an important role in the diagnosis of primary Sjogren's syndrome (PSS), but are not essential in seronegative PSS when there is at least one focus in minor salivary gland biopsy. The aim of this study was to compare the clinical and serological differences between patients with seropositive and seronegative PSS.

Materials and Methods: The study included 273 patients with PSS who were followed up at Kayseri City Training and Research Hospital, a tertiary hospital, between June 2018 and July 2021. The diagnosis of PSS was based on the 2016 American College of Rheumatology/European League Against Rheumatism PSS classification criteria. Autoantibodies were not detected in 45 (16.5\%) patients, and they were evaluated as having seronegative PSS. Clinical and laboratory parameter data of all the patients were collected retrospectively from the hospital database, and compared between the patients with seronegative PSS and patients with seropositive PSS.

Results: Females constituted $93.9 \%(\mathrm{n}=214)$ of the seropositive group and $91.1 \%(\mathrm{n}=41)$ of the seronegative group. The mean age at diagnosis was $47.87 \pm 9.07$ years in the seropositive group and $44.34 \pm 11.48$ years in the seronegative group $(\mathrm{p}=0.026)$. No statistically significant differences were determined between the groups in terms of sex distribution, clinical features, and the rate of patients with leukopenia, lymphopenia, thrombocytopenia, hypergammaglobulinemia, hypocomplementemia, and increased acute phase reactant. The median $\mathrm{C} 4$ value was lower, and the median IgG value was higher in the seropositive PSS group.

Conclusion: Clinical findings in patients with seronegative PSS overlapped with those of patients with seropositive PSS, but diagnosis was made later in patients with seronegative PSS.
\end{abstract}

Keywords: Sjogren's syndrome, rheumatoid factor, anti-CCP, ANA, anti-Ro, anti-SSA, anti-La

$\ddot{O} z$

Amaç: Romatoid faktör, anti-nükleer antikor, anti-Ro/SSA ve anti-La/SSB gibi otoantikorlar, primer Sjögren sendromunun (PSS) tanısında önemli bir role sahiptir, ancak minör tükürük bezi biyopsisinde en az bir fokus mevcut olduğunda seronegatif PSS tanısı için gerekli değildir. Bu çalışmada, seropozitif ve seronegatif PSS'li hastalar arasındaki klinik ve serolojik farklılıklar araştırılmıştır.

Gereç ve Yöntem: Haziran 2018-Temmuz 2021 tarihleri arasında üçüncü basamak bir hastane olan Kayseri Şehir Eğitim ve Araştırma Hastanesi’nde takip edilen 273 PSS'li hasta çalışmaya dahil edildi. PSS tanısı, 2016 Amerikan Romatoloji Koleji/Romatizmaya Karşı Avrupa Ligi PSS sınıflandırma kriterleri belirlenmiştir. Kırk beş (\%16.5) hastada otoantikor saptanmadı ve bu hastalar seronegatif PSS olarak değerlendirildi. Hastaların klinik ve laboratuvar parametreleri hastane veri tabanından geriye dönük olarak toplandı. Seronegatif ve seropozitif PSS'li hastaların klinik ve laboratuvar verileri karşılaştırıldı.

Bulgular: Seropozitif grupta 214 (\%93.9), seronegatif grupta 41 (\%91.1) kadın hasta vardı. Ortalama tanı yaşı seropozitifler için $47.87 \pm 9.07$ yıl ve seronegatifler için $44.34 \pm 11.48$ yıl olarak saptandı $(\mathrm{p}=0.026)$. Seronegatifler ve seropozitifler arasında cinsiyet dağılımı, klinik özellikler ve lökopeni, lenfopeni, trombositopeni, hipergamaglobulinemi, hipokomplementemi ve akut faz reaktanı artışı olan hasta sayısı açısından istatistiksel olarak anlamlı fark saptanmadı. Seropozitif PSS grubunda C4 ortanca değeri daha düşük, IgG ortanca değeri daha yüksek saptandı.

Sonuç: Seronegatif PSS'li hastalardaki klinik bulgular seropozitif PSS'li hastalardaki bulgular ile örtüşmektedir, ancak seronegatif PSS'li hastalarda daha geç tanı koyulmuştur.

Anahtar Kelimeler: Sjögren sendromu, romatoid faktör, anti-CCP, ANA, anti-Ro, anti-SSA, anti-La

ORCID: S. Karahan 0000-0003-2065-4047, A. Karabulut 0000-0002-2416-4507

${ }^{\circ}$ Copyright 2021 by the Turkish Society of Immunology. Turkish Journal of Immunology published by Galenos Publishing House.

Licenced by Creative Commons Attribution-NonCommercial-NoDerivatives 4.0 International (CC BY-NC-ND 4.0) 


\section{Introduction}

Sjogren's syndrome $(\mathrm{SjS})$ is a chronic, exocrineopathic autoimmune disease that causes inflammation especially in the salivary and lacrimal glands, and occasionally in the lungs, kidneys, joints, and central nervous system. ${ }^{[1]}$ Although $\mathrm{SjS}$ is seen more in middle-aged females, it can also be observed in children and males of advanced age. ${ }^{[1]}$ Secondary $\mathrm{SjS}$ is seen in individuals with systemic autoimmune diseases such as rheumatoid arthritis (RA), systemic sclerosis, systemic lupus erythematosus, inflammatory myopathies or organ-specific autoimmune diseases such as primary sclerosing cholangitis, autoimmune hepatitis, autoimmune thyroiditis, celiac disease, and multiple sclerosis. ${ }^{[2]}$ Primary SjS (PSS) is defined as the disease alone with no accompanying autoimmune disease. ${ }^{[2]}$ Although the majority of patients have benign symptoms, the disease may be serious with a high mortality rate that is mainly associated with systemic involvement and hematological malignancies. ${ }^{[2,3]}$

Although the origin of PSS is not known exactly, epithelial cells are at the center of the pathogenesis of immunopathological lesions. ${ }^{[2]}$ These cells appear to be activated, producing various cytokines and chemokines, and molecules capable of priming local immune responses. ${ }^{[4]}$ Human leukocyte antigen-DR (HLA-DR), interferongamma, interleukin-17 (IL-17), B-cell activating factor are among the most important natural and humoral immune system elements. ${ }^{[4]}$ As a result of this information, the term "autoimmune epithelitis" began to be used ${ }^{[5]}$ Lymphocytes are the most important immune cells in the pathogenesis of PSS. At the onset of disease with mild lesions, CD4 $4^{+}$ $\mathrm{T}$ lymphocytes constitute the main cell population in the exocrine glands, and B-cells become dominant as lesions progress in severity and over time. ${ }^{[6]}$ Follicular T-helper cells are a subset of $\mathrm{CD}^{+}{ }^{+}$-cells that express PD-1 (also known as CD279) and CXCR5 as cell surface receptors, stimulating the transformation of $\mathrm{B}$ cells into plasma cells and the consequent formation of lymphoid germinal centers. ${ }^{[6]}$ Experimental studies and clinical observations have shown that these continuously stimulated B-cells play an important role in hypergammaglobulinemia, increased levels of free light chains, an increased risk of B-cell lymphoma, and the presence of serum autoantibodies. ${ }^{[7]}$ Of these autoantibodies, anti-Ro/SSA and anti-La/SSB are important for disease classification. The 2016 American College of Rheumatology (ACR)/European League Against Rheumatism (EULAR) PSS classification criteria are the most recent criteria for clinical use. ${ }^{[8]}$ The anti Ro/ SSA antibodies are included in the 2016 ACR/EULAR classification criteria, whereas RF, ANA and anti - La/SSB positivities are not included. ${ }^{[8]}$ This was a change from the 2002 American-European Consensus Group criteria, in which both anti-Ro/SS and anti-La/SSB were included, and RF and ANA could not be used in classification. ${ }^{[9]}$ In the 2012 ACR criteria, which were also frequently used in clinical practice, anti-Ro/SSA, anti-La/SSB, RF and ANA were all mentioned as immunological criteria. ${ }^{[10]}$ The most important immunological criterion in the 2012 ACR criteria was that there should be both ANA with a titer of $\geq 1 / 320$ and RF positivity in patients with both anti-Ro/ SSA and anti-La/SSB negativity. ${ }^{[10]}$ Anti-CCP, which was relatively sensitive and specific for RA, was not included in any of the aforementioned PSS classification criteria. ${ }^{[8-10]} \mathrm{A}$ diagnosis of PSS can be made without the positivity of any of these antibodies, and this has been given the relatively new nomenclature of "seronegative PSS" ${ }^{[8]}$ The most important parameter in these patients is that the focus score in the biopsy from the minor salivary gland should be $\geq 1$.

The aim of this study was to examine the positivity of anti-Ro/SSA, anti-La/SSB, and RF, and ANA with a titer of $\geq 1: 160$, and to compare these laboratory parameters and clinical features of patients with seropositive PSS with those of patients with seronegative PSS in whom all four antibodies were negative.

\section{Materials and Methods}

The study included 273 patients with PSS who were followed up in the rheumatology outpatient clinic of Kayseri City Training and Research, a tertiary hospital, between June 2018 and July 2021. The patients comprised $255(93.4 \%)$ females and $18(6.6 \%)$ males. The diagnosis of PSS was made by a rheumatologist according to the 2016 ACR/EULAR PSS classification criteria, ${ }^{\left[{ }^{[7}\right.}$ in which PSS classification was established by the presence of anti-Ro/ SSA autoantibodies and/or histopathological examination of minor salivary gland samples, after laboratory confirmation of patient-reported dry mouth and/or dry eyes. Patients with secondary SjS were excluded from the study. The clinical and laboratory data of the patients were recorded on the electronic database of the hospital. Among the patients classified as PSS, those who were positive for any of the anti-Ro/SSA, anti-La/SSB, RF, and/or ANA with a titer of $\geq 1: 160$ autoantibodies constituted the seropositive patient population (seropositive PSS group). Patients who were not positive for any of these four antibodies constituted the seronegative patient population (seronegative PSS group).

The staining patterns of ANA were identified by indirect immunofluorescence (IIF) on HEp-20 - 10/Liver (Monkey) cell substrates [EUROStar III plus (EUROIMMUN Medizinische Labordiagnostika AG, Lübeck, Germany]. In line with the manufacturer's recommendations, sera were diluted 1/100 for ANA. The IIF preparates were read and interpreted by experienced microbiologists. The 
EUROLINE ANA Profile 3 plus (IgG) (EUROIMMUN Medizinische Labordiagnostika AG, Lübeck, Germany) test kit was used for the detection of antibodies against Ro/ SSA and La/SSB antigens. The EUROBlotMaster compact tabletop device with the Euro01 AAK EL30 program was used for automated incubation. The positivity value for IgM RF was determined using the nephelometric assay was $15 \mathrm{IU} / \mathrm{mL}$. A focus was defined as $>50$ lymphocytes in the lower lip minor salivary gland biopsy. ${ }^{[1]}$ In accordance with the 2016 ACR/EULAR classification criteria for PSS, the presence of one or more foci in an area of $4 \mathrm{~mm}^{2}$ was considered a "sufficient histopathological criterion".

Comorbidities and PSS-related organ involvement of the patients at any time during the follow-up period were recorded. The reference ranges of the hospital were used to determine whether or not the laboratory results were within the normal range.

The study was approved by the Ethics Committee of Kayseri City Training and Research Hospital (date: 01.07.2021, no: 427). All procedures were applied in compliance with the principles of the Declaration of Helsinki.

\section{Statistical Analysis}

Statistical analyses were performed using the Statistical Package for the Social Sciences version 25.0 software (IBM, Armonk, NY, USA). Rates of prevalence between the groups were compared using the chi-square test or Fisher's exact test, and comparison tables were constructed for variables showing significance. Conformity of the data to normal distribution was assessed with the Shapiro-Wilk test. In the comparison of groups of continuous data, the Student's t-test was applied to normally distributed data and the Mann-Whitney $U$ test to data not showing normal distribution. Spearman's correlation coefficient $\left(r_{s}\right)$ was used to evaluate correlations of parameters. Categorical variables were reported as number (n) and percentage $(\%)$, and continuous variables as mean \pm standard deviation or median value with interquartile range according to whether or not the data conformed to normal distribution. A two-tailed $p$ value of $<0.05$ was accepted as statistically significant.

\section{Results}

The seropositive PSS group included 228 patients, comprising 214 (93.9\%) females and 14 (6.1\%) males with a mean age of $47.9 \pm 12.0$ years. The seronegative PSS group included 45 patients, comprising 41 (91.1\%) females and $4(8.9 \%)$ males with a mean age of $51.1 \pm 9.2$ years ( $p=0.042$ for age, $p=0.511$ for gender). The mean age of the patients at the time of diagnosis was $47.9 \pm 9.1$ years in the seropositive PSS group and $44.3 \pm 11.5$ years in the seronegative PSS group $(\mathrm{p}=0.026)$. With the exception of age and age at diagnosis, no differences were determined between the groups in respect of demographic data (Table 1).

The most common autoantibody in the 228 patients with seropositive PSS was ANA, which was observed in $196(86 \%)$ patients. Anti-Ro antibody was positive in 96 (42.1\%) patients and RF was observed in 75 (32.9\%) patients. The least observed autoantibody was anti-La antibody, which was observed in $4(1.8 \%)$ patients.

Table 1. Demographic data between seropositive PSS and seronegative PSS groups.

\begin{tabular}{|c|c|c|c|}
\hline & $\begin{array}{l}\text { Seropositive PSS Group } \\
(\mathrm{n}=\mathbf{2 2 8})\end{array}$ & $\begin{array}{l}\text { Seronegative PSS Group } \\
(\mathrm{n}=45)\end{array}$ & p-value \\
\hline Age, years, mean \pm SD & $47.9 \pm 12.0$ & $51.1 \pm 9.2$ & 0.042 \\
\hline Age at diagnosis, years, mean \pm SD & $47.9 \pm 9.1$ & $44.3 \pm 11.5$ & 0.026 \\
\hline Gender, female, no (\%) & $214(93.9)$ & $41(91.1)$ & 0.511 \\
\hline BMI, $\mathrm{kg} / \mathrm{m}^{2}$, median (IQR) & $27.4(25.7-30.1)$ & $26.6(24.1-29.0)$ & 0.180 \\
\hline Race, non-Caucasian, no (\%) & $6(2.6)$ & $2(4.4)$ & 0.510 \\
\hline Current smoking, no (\%) & $63(27.6)$ & $16(35.6)$ & 0.284 \\
\hline \multicolumn{4}{|l|}{ Co-morbidities, no (\%) } \\
\hline - DM & $30(13.2)$ & $4(8.9)$ & 0.428 \\
\hline - HT & $12(26.7)$ & $76(33.3)$ & 0.382 \\
\hline - ASHD & $10(4.4)$ & $2(4.4)$ & 0.986 \\
\hline - Asthma/COPD & $8(3.5)$ & $2(4.4)$ & 0.760 \\
\hline - CKD & $5(2.2)$ & $3(6.7)$ & 0.104 \\
\hline - Depression/BAD & $31(13.6)$ & $6(13.3)$ & 0.962 \\
\hline - Thyroid dysfunction & $40(17.5)$ & $12(26.7)$ & 0.154 \\
\hline
\end{tabular}


The clinical characteristics of the seropositive PSS group and the seronegative PSS group are shown in Table 2. Therefore, biopsy was performed in all patients with seronegative PSS. Biopsy was performed in 157/228 $(68.9 \%)$ patients with seropositive PSS. The incidence of at least one focus in the minor salivary gland biopsy in the patients with seropositive PSS was 133/157 (84.7\%), and $45 / 45(100 \%)$ in the patients with seronegative PSS, as expected $(\mathrm{p}=0.005)$. As shown in Table 2, there was no statistically significant difference between the two groups in terms of the rate of patients with leukopenia, lymphopenia, thrombocytopenia, hypocomplementemia, hypergammaglobulinemia, and increased acute phase reactant. When the laboratory values of these parameters were compared, the median value of the $\mathrm{C} 4$ complement level was lower in the seropositive PSS group and the median value of the IgG level was higher [23 (18-29) vs $25(23-31) \mathrm{mg} / \mathrm{dL} ;(\mathrm{p}=0.003)$ and $1345(1104-1650)$ vs 1156 (1011-1377); $(\mathrm{p}=0.041)$, respectively]. The median erythrocyte sedimentation rate (ESR) value was higher in the seropositive PSS group, with no statistically significant difference determined between the groups [16 (10-26) vs $12(9-21) \mathrm{mg} / \mathrm{dL} ;(\mathrm{p}=0.061)]$.

All patients in the seronegative PSS group used antimalarial agents, and the rate of quinine use in the seropositive PSS group was 226/228 (99.1\%) ( $\mathrm{p}=1.000)$. In the seropositive PSS group one patient was taking azathioprine because of mild to moderate pulmonary involvement, and another patient was administered 4 cycles of cyclophosphamide because of severe non-specific

Table 2. Clinical characteristics between seropositive PSS and seronegative PSS groups.

\begin{tabular}{|c|c|c|c|}
\hline & $\begin{array}{l}\text { Seropositive PSS group } \\
(n=228)\end{array}$ & $\begin{array}{l}\text { Seronegative PSS group } \\
(n=45)\end{array}$ & p-value \\
\hline Patients with high APR, $(\%)$ & $127(55.7)$ & $21(46.7)$ & 0.266 \\
\hline - ESR, mm/h, median (IQR) & $16(10-26)$ & $12(9-21)$ & 0.061 \\
\hline - CRP, mg/L, median (IQR) & $3(1.1-6.35)$ & $3.8(1.5-6.25)$ & 0.494 \\
\hline Patients with leukopenia, no (\%) & $32(14.0)$ & $5(11.1)$ & 0.600 \\
\hline - Leukocyte, $\mathrm{x} 10^{3} / \mu \mathrm{L}$, median (IQR) & $6200(5200-8350)$ & $6410(5700-7900)$ & 0.695 \\
\hline Patients with lymphopenia, (\%) & $19(8.3)$ & $3(6.7)$ & 0.707 \\
\hline - Lymphocyte, $\mathrm{x} 10^{3} / \mu \mathrm{L}$, median (IQR) & $1676(1281-2192)$ & $1650(1306-2142)$ & 0.967 \\
\hline Patients with thrombocytopenia, $(\%)$ & $11(4.8)$ & $1(2.2)$ & 0.436 \\
\hline - Thrombocyte, $\times 10^{3} / \mu \mathrm{L}$, median (IQR) & $264(208.3-308.8)$ & $243(201.5-287.5)$ & 0.207 \\
\hline Patients with hypocomplementemia, n/n (\%) & 20/209 (9.6) & $3 / 44(6.8)$ & 0.563 \\
\hline - C3, mg/dL, median (IQR) & $129(106-150)$ & $126(112-151)$ & 0.869 \\
\hline - $\mathrm{C} 4, \mathrm{mg} / \mathrm{dL}$, median (IQR) & $23(18-29)$ & $25(23-31)$ & 0.003 \\
\hline Patients with hypergammaglobulinemia, n/n (\%) & $54 / 194(27.8)$ & $11 / 43(25.6)$ & 0.764 \\
\hline - IgG, g/dL, median (IQR) & $1345(1104-1650)$ & $1156(1011-1377)$ & 0.041 \\
\hline Focus score $\geq 1, \mathrm{n} / \mathrm{n}(\%)$ & $133 / 157(68.9)$ & $45 / 45(100)$ & 0.005 \\
\hline Arthralgia/arthritis, (\%) & $169(74.1)$ & $31(68.9)$ & 0.468 \\
\hline Raynaud's phenomenon, (\%) & $19(8.3)$ & $3(6.7)$ & 0.707 \\
\hline Pulmonary involvement, $(\%)$ & $30(12.1)$ & $3(6.7)$ & 0.222 \\
\hline \multicolumn{4}{|l|}{ Malignancy, no (\%) } \\
\hline - Solid & $8(3.5)$ & $2(4.4)$ & 0.672 \\
\hline - Hematologic & $2(0.9)$ & $2(4.4)$ & 0.069 \\
\hline Patients with livedo reticularis, (\%) & $20(8.8)$ & $5(11.1)$ & 0.578 \\
\hline Patients with vasculitis, (\%) & $2(0.9)$ & $1(2.2)$ & 0.429 \\
\hline Anti-phospholipid antibodies, n/n (\%) & $11 / 102(10.8)$ & $2 / 22(9.1)$ & 0.814 \\
\hline \multicolumn{4}{|l|}{ Number of patients with specidic treatments (\%) } \\
\hline - Hydroxychloroquine & $226(99.1)$ & $45(100)$ & 1.000 \\
\hline - Corticosteroids & $64(28.1)$ & $12(26.7)$ & 0.848 \\
\hline - Methotrexate & $29(12.7)$ & $3(6.7)$ & 0.248 \\
\hline - Anti-CD20 & $2(0.7)$ & 0 & 0.695 \\
\hline - Cholinergic therapy & $19(8.3)$ & $5(11.1)$ & 0.548 \\
\hline
\end{tabular}

PSS: Primary Sjogren's syndrome, APR: Acute phase reactant, ESR: Erythrocyte sedimentation rate, CRP: Erythrocyte sedimentation rate, IQR: Interquartile range, IgG: Immunoglobulin G, CD20: Cluster differentiation 20 
interstitial pneumonia, and then azathioprine was continued for maintenance. In summary, there was no statistically significant difference between the groups in terms of treatments, including the percentage of cholinergic therapy (pilocarpine/cevimeline).

The anti-Ro/SSA antibody, the only immunological marker in the 2016 ACR/EULAR classification criteria, was negatively correlated with leukocyte count $\left(\mathrm{r}_{\mathrm{s}}=-\right.$ $0.218, \mathrm{p}=0.002)$, lymphocyte count $\left(\mathrm{r}_{\mathrm{s}}=-0.127, \mathrm{p}=0.021\right)$, thrombocyte count $\left(\mathrm{r}_{\mathrm{s}}=-0.267, \mathrm{p}<0.001\right)$ and complement $\mathrm{C} 4$ level $\left(\mathrm{r}_{\mathrm{s}}=-0.226, \mathrm{p}<0.001\right)$, and was positively correlated with ESR $\left(\mathrm{r}_{\mathrm{s}}=0.169, \mathrm{p}=0.007\right)$ and $\mathrm{IgG}$ level $\left(\mathrm{r}_{\mathrm{s}}=0.346\right.$, $\mathrm{p}=0.001)$. $\mathrm{RF}$ positivity was correlated with arthritis/ arthralgia $\left(r_{s}=0.131, p=0.031\right)$, Raynaud's phenomenon $\left(r_{s}=0.635, p=0.039\right)$, and negatively correlated with complement $\mathrm{C} 4$ level $\left(\mathrm{r}_{\mathrm{s}}=-0.147, \mathrm{p}=0.019\right)$. No correlations were determined between ANA and anti-La/SSB antibodies and any of the clinical and laboratory parameters.

\section{Discussion}

The primary finding of this study was that there was no significant difference in the rate of clinical findings between patients with seronegative PSS and patients with seropositive PSS, but patients with seronegative PSS were diagnosed later. Although the number of patients with hypergammaglobulinemia and hypocomplementemia was similar in both groups, the median immunoglobulin level was higher and the $\mathrm{C} 4$ level was lower in patients with seropositive PSS. Another important finding of the study was that the highest rate of autoantibody positivity in the patients with seropositive PSS was anti-Ro antibody. The seronegative PSS population with no autoantibodies determined constituted $16.5 \%$ of all the patients with PSS.

The most important features of exocrinopathic disease are dry mouth and eyes, fatigue, and joint pain, and these three symptoms co-exist in $>80 \%$ of patients with PSS. ${ }^{[8]}$ The disease has a significant impact on quality of life and a subsequent decrease in work productivity. ${ }^{[12]}$ In a comparative study of the clinical and serological features of seronegative PSS, Yazisiz et al ${ }^{[13]}$ reported that the clinical data of patients with seronegative PSS and patients with seropositive PSS were similar, but there was a higher rate of patients with hypergammaglobulinemia in the seropositive PSS group. Partially similar to the finding of Yazisiz et al., ${ }^{[13]}$ it was seen in the current study that $\operatorname{IgG}$ levels were higher and $\mathrm{C} 4$ levels were lower in the patients with seropositive PSS. However, a difference in the current study was that seronegative patients were diagnosed at an older age. This was attributed to the fact that non-rheumatologist clinicians in the hospital did not sufficiently question dry mouth and eye symptoms when referring patients to rheumatology clinics and remained more dependent on the laboratory parameters. The analysis of ANA, RF or other autoantibodies as screening tests, without questioning sicca symptoms, may result in the earlier referral of patients with seropositive PSS to rheumatology clinics. This would be a very important and inevitable result of making time for the patient and asking the right questions with a full systemic inquiry.

Immunological markers that predict lymphoma development in PSS include hypocomplementemia, cryoglobulinemia, rheumatoid factor, hypergammaglobulinemia, serum monoclonal gammopathy, and anti-Ro/SSa antibody. ${ }^{[14]}$ AntiRo/SSA autoantibody has also been shown to be more common in patients with fetal congenital cardiac blocks and pulmonary involvement, but not in those with isolated neurological involvement. ${ }^{[15]}$ According to Baer et al. ${ }^{[16]}$, only about $2 \%$ of patients with $\mathrm{SjS}$ have anti-La/SSB antibodies without concomitant anti-Ro/SSA antibodies. In addition, according to another important result of the same study, the presence of anti-La/SSB without antiRo/SSA antibodies was not significantly associated with clinical findings of PSS compared to seronegative patients. Therefore, as the presence of anti-La/SSB antibodies alone provided no more support for the diagnosis of PSS, this serological profile was not included in the 2016 ACR/ EULAR PSS classification criteria in clinical practice. ${ }^{\left[{ }^{[8}\right.}$ However, the frequencies of arthritis/arthralgia, salivary gland enlargement, cutaneous vasculitis, leukopenia and lymphopenia, kidney involvement, Raynaud's phenomenon, and central nervous system involvement have been shown to be higher in RF positive patients with PSS than in those who are RF-negative. ${ }^{[17]}$ In the current study data, RF was seen to be correlated with arthritis/arthralgia and Raynaud's phenomenon, and negatively correlated with $\mathrm{C} 4$ level.

The strengths of this study were that it included a comparison of patients with seropositive PSS and patients with seronegative PSS and an analysis of correlations between some clinical and laboratory parameters. Nevertheless, there were also some limitations: This study was a single center study with cross-sectional design and with relatively small study population. Another limitation was that the rheumatological history, examination, and laboratory data of the patients were obtained from the medical records of the patients, and the follow-up period was relatively short (3.6 years).

\section{Conclusion}

This study compared clinical and laboratory findings in patients with seronegative PSS with those of patients with seropositive PSS. Patients with seronegative PSS demonstrated similar changes in clinical and laboratory findings as those with seropositive PSS, including the rates of patients with increased acute phase reactant, thrombocytopenia, lymphopenia, leukopenia, hypergammaglobulinemia, and 
hypocomplementemia. There is a need for further longitudinal studies of larger cohorts to confirm these results and to elucidate the roles of autoantibodies in PSS.

\section{Ethics}

Ethics Committee Approval: The study was approved by the Ethics Committee of Kayseri City Training and Research Hospital (date: 01.07.2021, no: 427). All procedures were applied in compliance with the principles of the Declaration of Helsinki.

Informed Consent: Retrospective study.

Peer-review: Externally peer-reviewed.

\section{Authorship Contributions}

Concept: S.K., Design: S.K., Data Collection or Processing: S.K., A.K., Analysis or Interpretation: S.K., Literature Search: S.K., A.K., Writing: S.K.

Conflict of Interest: No conflict of interest was declared by the authors.

Financial Disclosure: The authors declare that they have no relevant financial.

\section{References}

1. Bjordal O, Norheim KB, Rødahl E, Jonsson R, Omdal R. Primary Sjögren's syndrome and the eye. Surv Ophthalmol. 2020;65(2):119-32. [CrossRef]

2. Lee AS, Scofield RH, Hammitt KM, Gupta N, Thomas DE, Moua T, et al; Consensus Expert Panel (CEP) Members. Consensus Guidelines for Evaluation and Management of Pulmonary Disease in Sjögren's. Chest. 2021;159(2):683-98. [CrossRef]

3. Retamozo S, Brito-Zerón P, Ramos-Casals M. Prognostic markers of lymphoma development in primary Sjögren syndrome. Lupus. 2019;28(8):923-36. [CrossRef]

4. Tzioufas AG, Kapsogeorgou EK, Moutsopoulos HM. Pathogenesis of Sjögren's syndrome: what we know and what we should learn. J Autoimmun. 2012;39(1-2):4-8. [CrossRef]

5. Mavragani CP, Moutsopoulos HM. Sjögren's syndrome: old and new therapeutic targets. J Autoimmun. 2020;110:102364. [CrossRef]

6. Chen W, Yang F, Xu G, Ma J, Lin J. Follicular helper T cells and follicular regulatory $\mathrm{T}$ cells in the immunopathology of primary Sjögren's syndrome. J Leukoc Biol. 2021;109(2):437-47.
7. Nocturne G, Mariette X. B cells in the pathogenesis of primary Sjögren syndrome. Nat Rev Rheumatol. 2018;14(3):133-45. [CrossRef]

8. Shiboski CH, Shiboski SC, Seror R, Criswell LA, Labetoulle M, Lietman TM, et al. 2016 American College of Rheumatology/ European League Against Rheumatism classification criteria for primary Sjögren\&\#039;s syndrome. Ann Rheum Dis. 2017;76(1):9-16. [CrossRef]

9. Vitali C, Bombardieri S, Jonsson R, Moutsopoulos HM, Alexander EL, Carsons SE, et al. Classification criteria for Sjögren's syndrome: a revised version of the European criteria proposed by the American-European Consensus Group. Ann Rheum Dis. 2002;61(6):554-8. [CrossRef]

10. Shiboski SC, Shiboski CH, Criswell LA, Baer AN, Challacombe $\mathrm{S}$, Lanfranchi $\mathrm{H}$, et al. American College of Rheumatology classification criteria for Sjögren's syndrome: a data-driven, expert consensus approach in the Sjögren's International Collaborative Clinical Alliance cohort. Arthritis Care Res (Hoboken). 2012;64(4):475-87. [CrossRef]

11. Daniels TE, Cox D, Shiboski CH, Schiødt M, Wu A, Lanfranchi $\mathrm{H}$, et al. Associations between salivary gland histopathologic diagnoses and phenotypic features of Sjögren's syndrome among 1,726 registry participants. Arthritis Rheum. 2011;63(7):202130. [CrossRef]

12. Meijer JM, Meiners PM, Huddleston Slater JJR, Spijkervet FKL, Kallenberg CGM, Vissink A, et al. Health-related quality of life, employment and disability in patients with Sjogren's syndrome. Rheumatology (Oxford). 2009;48(9):1077-82. [CrossRef]

13. Yazisiz V, Aslan B, Erbasan F, Uçar İ, Öğüt TS, Terzioğlu ME. Clinical and serological characteristics of seronegative primary Sjögren's syndrome: a comparative study. Clin Rheumatol. 2021;40(1):221-9.

14. Kapsogeorgou EK, Voulgarelis M, Tzioufas AG. Predictive markers of lymphomagenesis in Sjögren's syndrome: From clinical data to molecular stratification. J Autoimmun. 2019;104:102316. [CrossRef]

15. Brito-Zerón $\mathrm{P}$, Baldini $\mathrm{C}$, Bootsma $\mathrm{H}$, Bowman SJ, Jonsson $\mathrm{R}$, Mariette X, et al. Sjögren syndrome. Nat Rev Dis Prim. 2016;2(1):16047. [CrossRef]

16. Baer AN, McAdams DeMarco M, Shiboski SC, Lam MY, Challacombe S, Daniels TE, et al. The SSB-positive/SSA-negative antibody profile is not associated with key phenotypic features of Sjögren's syndrome. Ann Rheum Dis. 2015;74(8):1557-61. [CrossRef]

17. Ramos-Casals M, Solans R, Rosas J, Camps MT, Gil A, Del PinoMontes J, et al. Primary Sjögren syndrome in Spain: clinical and immunologic expression in 1010 patients. Medicine (Baltimore). 2008 ;87(4):210-9. [CrossRef] 